\title{
The relationship between salivary secretion and taste sensitivity level in the elderly
}

\author{
Fimma Naritasari, Dewi Agustina, Supriatno \\ Department of Oral Medicine, Faculty of Dentistry, Universitas Gadjah Mada, Yogyakarta, Indonesia \\ JI Denta No 1 Sekip Utara, Yogyakarta, Indonesia; e-mail: drgfimmanarita@mail.ugm.ac.id
}

Submitted: $5^{\text {th }}$ July 2018; Revised: 14 ${ }^{\text {th }}$ August 2018; Accepted: $13^{\text {rd }}$ November 2018

\begin{abstract}
The increasing population of the elderly has an impact on health problems, including an increase of oral problems. One of the common oral problems is dry mouth that possibly disrupts gustatory function. The aim of this study was to investigate the relationship between salivary secretion and taste sensitivity level in the elderly. This study was a cross sectional study for the elderly population of Daerah Istimewa Yogyakarta/The Special Region of Yogyakarta (DIY) Province, Indonesia. This study consisted of interview, clinical examination, measurement of salivary secretion (sialometry) and taste sensitivity level using chemical gustometry method. Salivary secretion data were described in $\mathrm{ml} / \mathrm{min}$. The measurement of taste sensitivity level was performed using 4 different substances: sweet (sucrose), salty $(\mathrm{NaCl})$, sour (citric acid) and bitter (quinidine sulphate) with 4 different concentrations for each flavor. Four score was given if the respondent recognized the lowest concentration of the substance and 0 score was provided when all concentrations were failed to be tasted. Total score for test sensitivity level was scaled from 0 to 16 . Salivary secretion data and taste sensitivity level data were analyzed by Spearman correlation test to determine the correlation between both variables. There were 103 subjects ( 70 women and 33 men) with the age mean of 65.61 years old, participating in this study. The mean of the sweet taste level was 2.81, 3.32 for salty taste, 3.69 for sour taste and 2.98 for bitter taste. Total taste sensitivity level mean was 12.80 out of 16 . The measurements of unstimulated whole saliva showed a mean value of $0.170 \mathrm{ml} / \mathrm{min}$ with the majority of subjects having normal salivary flow. The Spearman correlation test results showed $r=-0.078$ with $p>0.05$ that indicated no correlation. We concluded that there was no relationship between salivary secretion and taste sensitivity level in the elderly.
\end{abstract}

Keywords: salivary secretion; taste sensitivity level; the elderly

\section{INTRODUCTION}

The number of elderly people in the world is increasing every year, including in Indonesia. In 2012, Indonesia ranked third in Asia with 25 million numbers of elderly population, after China (200 million) and India (100 million). It was estimated that by 2050 , the number of elderly people in Indonesia would have amounted to 100 million. ${ }^{1}$ In 2010, the proportion of elderly population in Indonesia reached about $7.18 \%$, surpassing the range percentage to be classified as "aging society". The Special Region of Yogyakarta (DIY) is a province with the highest elderly population in Indonesia with the percentage of elderly population of $13.04 \%$ in year of 2010. ${ }^{2}$ This condition is related to the life expectancy in DIY that is 73,72 years, which is the longest in Indonesia. ${ }^{3}$
The enhanced life expectancy promoted the increasing number of chronic diseases incidence that affected general and oral health. The common oral health problem in the elderly includes mucosal diseases of the oral cavity, infectious diseases, tooth diseases, periodontal disease, salivary gland dysfunction, olfactory and tasting dysfunction, gastrointestinal disorders, and edentulous conditions. ${ }^{4}$ Of all these conditions, dry mouth was considered as one of the main problems suffered by the elderly. Ship et al. ${ }^{4}$ estimated that $30 \%$ of the population aged 65 years and over experienced dry mouth disorders.

The function of saliva is to maintain the integrity of the hard and soft tissues of the oral cavity, as well as to support the speech, swallowing, and tasting process. ${ }^{5}$ Saliva plays an important role as 
a solvent of taste substances, but the prevalence of dysgeusia and hypogeusia are increasing in patients with a decreasing salivary gland function. ${ }^{6}$ Reduced salivary secretion leads to dryness of oral mucosa and accelerates a damage on the taste receptor cells. ${ }^{7}$ In patients with chronic xerostomia as in Sjögren syndrome or after head and neck radiotherapy, a decrease of the ability to recognize the tasting stimulation was discovered. ${ }^{8}$

The association between the salivary function with the taste sensitivity level is controversial. Weiffenbach et al. ${ }^{9}$ reported that the taste acuity remained normal in eight patients with impaired salivary gland function, suggesting a possibility of no effect of the salivary gland function on the normal taste perception. This finding is similar with the results of Akal et al. ${ }^{10}$ evaluation of the various factors that affect the taste perception. In the study, there was no difference on taste sensitivity levels of the four basic flavors (sweet, salty, sour, and bitter) in the subject with dry mouth due to drug consumption. The same statement was expressed by Fox and Eversole, ${ }^{6}$ who revealed that tasting ability persisted without the presence of major salivary gland functions. Nevertheless, in Brosvic and Hoey ${ }^{11}$ research, a reduction in sensitivity to salty, sour and bitter flavors was found in rats after major salivary glands removal. The study by Satoh-Kuriwada et al. ${ }^{12}$ also suggested that a hyposalivation had a strong influence on the hypogeusia in the elderly.

The taste sensitivity problem in the elderly is often overlooked because it is considered unimportant for life. The decrease of tasting ability may lead to an appetite reduction, which promotes a weight loss, malnutrition, impaired immunity, and worsening health conditions. ${ }^{13}$ The tasting disorder affects food selection, which is no longer based on the nutrition but what is more desirable. ${ }^{14}$ The elderly tend to consume sugar and salt excessively to compensate the decrease in taste sensitivity. This condition will certainly influence the general health of the elderly. ${ }^{13}$ The frequent salivary gland disorder and its correlation with the taste sensitivity problem in the elderly requires further researches. These researches are important because both salivary problem and decrease of taste sensitivity influence the general health condition of the elderly. The aim of this study was to investigate the relationship between salivary secretions to taste sensitivity level in the elderly population in the Special Region of Yogyakarta (DIY).

\section{MATERIALS AND METHODS}

This research was a cross sectional study on the elderly population of the Special Region of Yogyakarta. The participants were recruited from the community health station for the elderly (Posyandu Lansia) and were selected using multistage cluster random sampling method. The examination and data collection were performed in Prof. Soedomo Dental Hospital, Universitas Gadjah Mada. The criteria of inclusion were including the minimum age of 60 years, the ability to independently perform daily activities, and the ability to do verbal communication. The exclusion criteria of this study were including undergoing chemotherapy/ radiotherapy, currently hospitalized, confessing a smoking habit, and living in a nursing home. All subjects who agreed to join this research signed the informed consent form prior to the study. All treatment performed in this study was approved by the Ethics and Advocacy Unit of Faculty of Dentistry, Universitas Gadjah Mada (00723/KKEP/FKG-UGM/EC/2016).

The data were collected by interview method (anamnesis), anthropometric examination, extraoral and intraoral clinical examination, salivary secretion measurement using sialometry and sensitivity level measurement. Interview was performed by our research assistant using a spesific research instrument to obtain sociodemographic data (age, gender, and educational level), medical history, and medication history. The instrument consisted of close question to limit the answer variation, thus a calibration were not required. Anthropometric examination to determine the nutritional status by body mass index was conducted by measuring body height and weight. Extraoral and intraoral clinical examination were performed by 3 trained and calibrated dentist to obtain information on oral hygiene, denture wear and oral lesion. The 
Majalah Kedokteran Gigi Indonesia. December 2018; 4(3): 134 - 141

ISSN 2460-0164 (print)

ISSN 2442-2576 (online)

participants were prevented from eating and drinking at least 1 hour before the salivary secretion and sensitivity level test. The examination of salivary secretion was conducted in the morning between $8 \mathrm{am}$ to 10 am by measuring the total volume of unstimulated salivary secretion in 5 minutes by spitting method. The salivary secretion data was expressed as the average of salivary secretion volume measured per minute. The taste sensitivity level test using 4 types of chemical solution with 4 different concentrations was referred from Mueller et al. ${ }^{15}$ The test was using: 1) sucrose in the concentration of $0.05,0.1,0.2$, and $0.4 \mathrm{~g} / \mathrm{ml}$ to induce sweet perception; 2) sodium chloride/ $\mathrm{NaCl}$ in the concentration of $0.016,0.04,0.01$, and 0.25 $\mathrm{g} / \mathrm{ml}$ for salty taste, 3 ) citric acid for sour taste in the concentration of $0.0125,0.0225,0.041$, and 0.075 $\mathrm{g} / \mathrm{ml}$; and 4) quinidine sulphate in the concentration of $0.0001,0.0002,0.0006$, and $0.0015 \mathrm{~g} / \mathrm{ml}$ for bitter taste. The solution was applied by three drop methods. Three drops of each solution were placed on the dorsum area of the tongue with approximately $1.5 \mathrm{~cm}$ distance.

The participants were given score 4 when they recognized the lowest concentration of the substance and the score 0 if no concentration was detected by the participant. The score of total taste sensitivity level was a combination of all of basic tastes and ranged from 0 to 16. The data were statistically analyzed using Spearman correlation test with the level of significance of $0.05 \%$ and confident interval of $95 \%$ to determine the relationship between the salivary secretion and the taste sensitivity level in elderly.

\section{RESULTS}

The study involved 103 participants comprising of 70 women and 33 men, with an age range of 60-84 years (mean: 65.61 years). The subject came from several areas in DIY (Sub-district of Pundong, Wirobrajan, Sewon, Ngemplak, Berbah, and Kasihan). Subject characteristics based on interview results are presented in Table 1.

From Table 1, it can be seen that although one of the inclusion criteria of the elderly subject was being considered healthy, the research showed that almost all subjects had medical systemic background/problems. The most common condition found in the elderly subject was hypertension with a total number of 19 subjects (18.45\%). This was followed by the number of subjects who used routine medications related to systemic diseases. The most frequent type of drugs used by the subject was antihypertensive drugs by as many as 15 subjects $(14.56 \%)$.

Table 1. Participant's characteristic (n-103)

\begin{tabular}{|c|c|c|c|}
\hline & Variables & $n$ & Percentage (\%) \\
\hline Gender & Male & 33 & 32.04 \\
\hline & Female & 70 & 67.96 \\
\hline Age & 60-69 у.о. & 85 & 82.52 \\
\hline & 70-79 у.о. & 15 & 14.56 \\
\hline & $80-89$ у.о. & 3 & 2.91 \\
\hline Educational level & No formal education & 9 & 8.74 \\
\hline & Elementary school & 35 & 33.98 \\
\hline & Junior high school & 10 & 9.71 \\
\hline & Senior high school & 30 & 29.13 \\
\hline & University/college & 17 & 16.50 \\
\hline Ethnicity & Javanese & 103 & 100.00 \\
\hline & Non javanese & 0 & 0.00 \\
\hline Medical history & Without systemic medical background/problems & 28 & 27.18 \\
\hline & With systemic medical background/problems & 75 & 72.82 \\
\hline Medication & Without routine medications & 39 & 37.86 \\
\hline & Without routine medications (at least one type of drug) & 64 & 62.14 \\
\hline Smoking habit* & Never smoke & 87 & 84.47 \\
\hline & Ex-smoker & 16 & 15.53 \\
\hline
\end{tabular}

*Subjects who are still actively smoking are excluded from this study 
Table 2. Anthropometric measurement and clinical examination of the oral cavity $(n=130)$

\begin{tabular}{|c|c|c|c|}
\hline & Variables & $\mathrm{n}$ & $\begin{array}{c}\text { Percentage } \\
(\%)\end{array}$ \\
\hline \multirow{4}{*}{ Body mass Index } & Underweight & 10 & 9.71 \\
\hline & Normal & 63 & 61.17 \\
\hline & Overweight & 30 & 29.13 \\
\hline & $0-10$ teeth & 12 & 11.65 \\
\hline \multirow[t]{2}{*}{ Number of teeth } & $11-20$ teeth & 35 & 33.98 \\
\hline & $>20$ teeth & 56 & 54.37 \\
\hline \multirow{2}{*}{ Denture wearing } & With denture & 15 & 14.56 \\
\hline & Without denture & 88 & 85.44 \\
\hline \multirow{4}{*}{ Oral hygiene Index } & Good & 14 & 13.59 \\
\hline & Fair & 18 & 17.48 \\
\hline & Poor & 68 & 66.02 \\
\hline & Unclassified & 3 & 2.91 \\
\hline \multirow{3}{*}{ Saliva secretion } & Hyposalivation & 6 & 5.83 \\
\hline & Normal & 94 & 91.26 \\
\hline & Hypersalivation & 3 & 2.91 \\
\hline
\end{tabular}

Table 3. Mean of taste sensitivity level measurement

\begin{tabular}{llccccc}
\hline & & $\begin{array}{c}\text { Mean and SD } \\
\text { of total taste } \\
\text { sensitivity level }\end{array}$ & $\begin{array}{c}\text { Mean and SD } \\
\text { of sweet taste } \\
\text { sensitivity level }\end{array}$ & $\begin{array}{c}\text { Mean and SD } \\
\text { of salty taste } \\
\text { sensitivity level }\end{array}$ & $\begin{array}{c}\text { Mean and SD } \\
\text { of sour taste } \\
\text { sensitivity level }\end{array}$ & $\begin{array}{c}\text { Mean and SD } \\
\text { of bitter taste } \\
\text { sensitivity level }\end{array}$ \\
\hline Total subject & & $12.80 \pm 2.07$ & $2.81 \pm 1.02$ & $3.32 \pm 0.88$ & $3.69 \pm 0.65$ & $2.98 \pm 1.11$ \\
Saliva secretion & Hyposalivation & $14.33 \pm 1.60$ & $3.5 \pm 0.50$ & $3.67 \pm 0.47$ & $3.67 \pm 0.75$ & $3.5 \pm 0.76$ \\
& Normal & $12.67 \pm 2.09$ & $2.76 \pm 1.03$ & $3.30 \pm 0.66$ & $3.68 \pm 1.12$ & $2.94 \pm 2.09$ \\
& Hypersalivation & $13.67 \pm 0.47$ & $3 \pm 0.82$ & $3.33 \pm 0.47$ & $4 \pm 0.00$ & $3.33 \pm 0.94$ \\
\hline
\end{tabular}

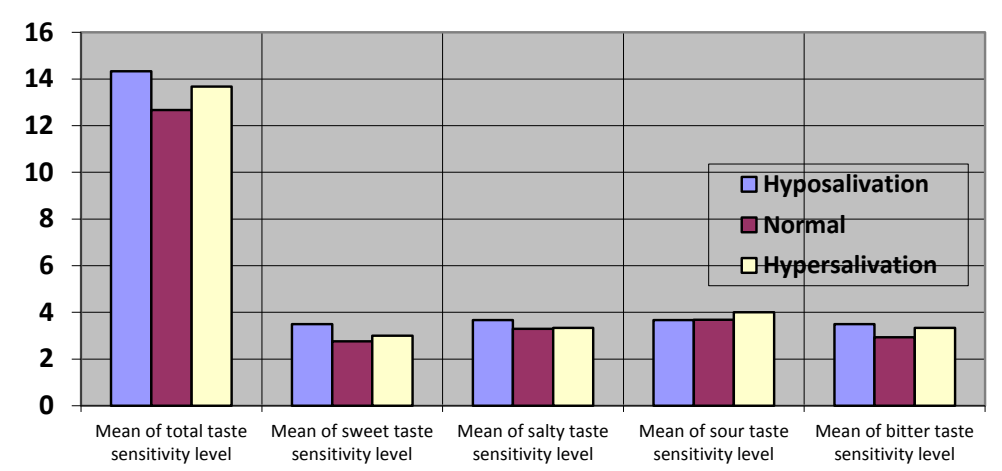

Figure 1. Graphic comparison of taste sensitivity level mean in hypersalivation normal salivation, and hyposalivation

The results of anthropometric measurements (Body Mass Index/BMI) and oral cavity examinations were presented in Table 2. Body mass index, denture wearing, oral hygiene index were recorded because they were uncontrollable variables that could affect the results of the study. The result of the salivary secretion measurement would be classified into 3 category: hyposalivation if less than $0.1 \mathrm{ml} / \mathrm{min}$, normal if between $0.1-1 \mathrm{ml} /$ $\mathrm{min}$, and hypersalivation if more than $1 \mathrm{ml} / \mathrm{min}^{16}$
Table 3 showed that the most decreasing taste sensitivity level was sweet taste with mean of 2.81 from the maximum score of 4 . The most sensitive taste felt by the elderly group was the sour taste with the mean of sensitivity level of 3.69. Based on this study, the lowest mean of taste sensitivity level occurred more in the group with normal salivary secretion than the other two groups. It can also be seen from the graph in Figure 1. 
The initial hypothesis of this study was a relation between salivary secretion with the taste sensitivity level. The results of the correlation analysis are presented in Table 4. Based on the Spearman correlation test results there were no significant correlations between salivary secretion and all of taste sensitivity level in the elderly in DIY ( $p>0.050$ ), as a result $\mathrm{H} 0$ was rejected.

Table 4. Spearman correlation test results between saliva secretion and taste sensitivity level

\begin{tabular}{llc}
\hline Dependent variable & \multicolumn{2}{c}{$\begin{array}{c}\text { Independent variable } \\
\text { saliva secretion }\end{array}$} \\
\hline $\begin{array}{l}\text { Total taste sensitivity } \\
\text { level }\end{array}$ & Correlation coefficient $(r)$ & -0.078 \\
Sweet taste sensitivity & -value & 0.431 \\
level & Correlation coefficient $(r)$ & 0.025 \\
Salty taste sensitivity & Correlation coefficient $(r)$ & -0.48 \\
level & p-value & 0.629 \\
Sour taste sensitivity & Correlation coefficient $(r)$ & 0.105 \\
level & $p$-value & 0.293 \\
Bitter taste sensitivity & Correlation coefficient $(r)$ & -0.153 \\
level & $p$-value & 0.123 \\
\hline
\end{tabular}

\section{DISCUSSION}

This study showed that there was no significant correlation between taste sensitivity level and salivary secretion. Several studies previously conducted by Weiffenbach et al. ${ }^{9}$ revealed that 8 patients with impaired salivary secretions showed a normal degree of taste sensitivity. The same conclusion was also obtained from the study of Akal et al. ${ }^{10}$ that from several factors affecting perception of tasting, dry mouth due to medication did not result in significant differences in taste sensitivity level of 4 basic taste (sweet, salty, sour, bitter). A different result is reported by Satoh-Kuriwada et al. ${ }^{12}$ which suggests that hyposalivation conditions were closely related to hypogeusia conditions. In this study, the majority of subjects had normal salivary secretions, with the measurement of unstimulated whole saliva between $0.1-1 \mathrm{ml} / \mathrm{min}$ and only $2.91 \%$ of subjects experiencing hyposalivation. The different result of this study as compared to the previous study might lead to less number of subjects experiencing hyposalivation. The small number of hyposalivation subject might be the reason for the lack of representation of hyposalivation group.

In elderly population, the condition of dry mouth (xerostomia) is generally caused by the condition of the polypharmacy. In the study of de Deco et al, ${ }^{17}$ the main side effects of the drugs by the elderly were the change of taste perception and dry mouth sensation related to antihypertensive drugs as the main drug agent that often causes dry mouth. In this study, of all 6 subjects who experienced hyposalivation, only 1 subject who consumed antihypertensive drugs of nifedipine, the other 1 subject used herbal treatment (not mentioned specifically), and others claimed not consuming any routine medication. This shows that the effect of medication on the secretion of salivary elderly also varied. When looking at the background of systemic disease, 6 subjects who experienced hyposalivastion, 3 of them claimed to have problems with high uric acid levels. The high association of uric acid with salivary secretions has not been widely studied, although high levels of uric acid are often associated with predisposing factors for sialolithialis or obstruction of salivary glands. ${ }^{18}$

Association between aging and hyposalivation conditions, according to Percival et al $^{19}$ showed generally a significant decrease of unstimulated salivary secretion commonly found in subjects aged 80 years old and above. This explains the least number of subjects with hyposalivation in this study, since the number of subjects aged 80 years old and above only amounted to 3 subjects and all them had normal salivary secretions. Thus, to prove the effect of aging on salivary gland secretions, it is necessary to increase the age range of the subject to an older age. The difficulty of finding subjects with age above 80 years in DIY caused by the life expectancy in DIY that only reached about 73.72 years old. ${ }^{2}$

In subjects with hyposalivation conditions, the average rate of taste sensitivity level was 14.33 or the highest of all other groups (normal salivation and hypersalivation). The decrease in salivary secretion has no direct effect on the gustatory function. Other possibilities was hyposalivation condition of the subject, not a condition that had lasted long. 
According to Engelen et al. ${ }^{20}$ decreased salivary secretions in short-term exhibit very little effect on taste perception, and long-term salivary deficiency will decrease the salivary sensitivity, causing a decrease in taste sensitivity. The results of the study of Akal et al ${ }^{10}$ also concluded that salivary amounts, although only slightly, was sufficient to induce the taste mechanism. In this study, the taste was tested in the solution form with aquades as a solvent. The saliva function as a tastant solvent was replaced by the aquades. This is supported by the revelation of Matsuo ${ }^{21}$ that the most important component of saliva to maintain taste sensitivity is water.

Decreased taste sensitivity level in healthy elderly without medication to basic flavors such as sucrose (sweet), $\mathrm{NaCl}$ (salty), quinine $\mathrm{HCl}$ (bitter), and citric Acid (Acid) is rare or mild. The cause of decreased taste sensitivity level in normal aging process, without disease, medication, or other medical intervention, is not fully understood..$^{22}$ The elderly patients with more drug to consume had a greater potential in decrease of taste sensitivity level. In this study, most of subjects (62.14\%) routinely consume at least 1 type of medication. This is most likely to cause a decrease in taste level on all flavors (mean each flavor more than 4). In addition, it is possible that there is a systemic disease or disorder that have never been realized yet by the subject. Another factor that affects salivary secretion and taste sensitivity is the use of denture. ${ }^{23}$ Based intraoral examination, of 103 subjects, only 15 people $(14.56 \%)$ were found to use denture. The rest of the subject did not use denture even though there was an edentulous area in the teeth. According to Tango et al, denture wear may help increase salivary secretion, but does not increase taste sensitivity. ${ }^{24}$ This decrease in taste sensitivity may also be associated with oral hygiene conditions. In this recent study, the majority $(66.02 \%)$ of subjects had a poor oral hygiene index $(\mathrm{OHI})$. The dirty mouth condition affected the taste sensitivity level. This affection is caused by acidic substance from bacterial tongue, which induces acidic taste. ${ }^{25}$

This study showed different mean of taste sensitivity level of each basic taste (sweet, salty, sour, and bitter) in the elderly. Differences in taste perception are strongly influenced by the organic and inorganic components of saliva. ${ }^{21}$ Previous study showed that high salivary $\mathrm{pH}$ (base) showed salivary buffering ability due to the presence of bicarbonate ion components that have improved sweet taste response by affecting tasting receptors. ${ }^{26}$ In contrast, the presence of bicarbonate ions will decrease the intensity of acidic taste. ${ }^{27}$ In this study, we did not measured salivary $\mathrm{pH}$ and salivary components, so it can not be known the effect of salivary quality on taste sensitivity level, which becomes the limitation of this study.

The lowest mean of taste sensitivity level in this study was for sweet taste with only 2.81 . This decrease in the sensitivity level of this sweet taste can occur because of an increase in excessive sugar intake in diabetes mellitus patients. ${ }^{28}$ In this study, there were 8 recorded subjects, who are known to have diabetes mellitus. In addition, one of the effects of aging on the tongue is the presence of atrophy on papilla-papilla tongue. ${ }^{29}$ In the study of Solemdal et al. ${ }^{25}$ the atrophic conditions of the tongue is associated with reduced sweet taste sensitivity greater than other taste sensitivity. A similar mechanism may occur in a decrease in salty taste sensitivity. Hypertensive patients generally have decreased levels of taste sensitivity to salty taste $(\mathrm{NaCl})$. This often leads to the fact that hypertensive patients having difficulty limiting salt intake because they feel more tasteless dish..$^{28}$ In this study, there were 19 subjects who have been known to suffer from hypertension and only 15 who take antihypertensive drugs. In addition, the perceptions of sweet and salty taste are two taste perceptions that often interfere with dry mouth conditions. ${ }^{25}$

This decrease of taste sensitivity in the elderly, though often neglected, can have an impact on the health conditions of the elderly by affecting decreased appetite, weight loss, malnutrition, and immune disorders. ${ }^{13}$ In this study, we realize that we still have weakness and limitation that should be taken into consideration. One of the weaknesses is that the number of subject with hyposalivation found in this study was very small leading to a lack of representation. Further research with more 
adequate number of subjects and representative enough to represent subject with hyposalivation is strongly recommended. In addition to the crosssectional study design, the mechanisms associated with the relationship between salivary secretion and taste level sensitivity have not been fully understood. Therefore, a more in-depth study of the condition of taste sensitivity is needed to support the better quality of life of the elderly.

\section{CONCLUSION}

The conclusion of this study is that there were no relationship between salivary secretion and taste sensitivity level in the elderly in Yogyakata.

\section{ACKNOWLEDGMENT}

This research is supported by Hibah Dana Masyarakat, Faculty of Dentistry, Universitas Gadjah Mada (No: 4780/KG/PP/2016).

\section{REFERENCES}

1. Abikusno N. Kelanjutusiaan sehat menuju masyarakat sehat untuk segala usia. Buletin Jendela Data dan Informasi Kesehatan Semester 1. Pusat Data dan Informasi Kemenkes RI (Ed.). Jakarta: Kemenkes RI; 2013. 25-28.

2. Badan Pusat Statistik. Statistik penduduk usia lanjut Indonesia 2010: hasil sensus penduduk 2010. Badan Pusat Statistik. Jakarta; 2012. 19-26.

3. Dinas Kesehatan Daerah Istimewa Yogyakarta. Profil Kesehatan Daerah Istimewa Yogyakarta tahun 2013. Dinkes DIY. Yogyakarta; 2013. 7-12.

4. Ship JA. Geriatrics in Greenberg MS and Glick M, Burket's Oral Medicine: Diagnosis and Treatment $10^{\text {th }}$ ed. Ontario: B.C. Decker Inc; 2003. 605-622.

5. Almeida PDV, Gregio AMT, Machado MAN, Lima AASL, Azevedo LR. Saliva composition and function: a comperehensive review. J Contemp Dent Pract. 2008; 9(3): 1-11.

6. Fox PC, Eversole LR. Disease of the salivary gland, in Silverman S, Eversole LR, Truelove
EL, Essential of oral medicine. Hamilton: BC Decker Inc; 2001. 260-276.

7. Heckmann JG, Heckmann SM, Lang CJG, Hummel T. Neurological aspect of taste disorders. Arch Neurol. 2003; 60(5): 667-671.

8. Turner MD, Ship JA. Dry mouth and its effects on the oral health of elderly people. J Am Dent Assoc. 2007; 138(9 supplement): 15S-20S.

9. Weiffenbach JM, Fox PC, Baum BJ. Taste and salivary function. Proc Natl Acad Sci. 1986; 83: 6103-6106.

10. Akal UK, Delilbasi C, Yilmaz T, Redzep E, Sertkaya D. Evaluation of some factors affecting taste perception. OHDMBSC. 2003; 2(4): 33-37.

11. Brosvic GM, Hoey NE. Taste detection and discrimination performance of rats following selective desalivation. Physiol Behav. 1990; 48: 617-623.

12. Satoh-Kuriwada S, Shoji N, Kawai M, Uneyama $\mathrm{H}$, Kaneta N, Sasano T. Hyposalivation strongly influenced hypogeusia in the elderly. Journal of Health Science. 2009; 55(5): 689-698.

13. Boyce JM, Shone GR. Review: effects of ageing on smell and taste. Postgrad Med J. 2006; 82: 239-241.

14. Floch JP, Lievre GL, Sadoun J, Perlemuter L, Peynegre R, Hazard J. Taste impairment and related factor in type 1 Diabetes mellitus. Diabetes Care. 1989; 26(2): 173-178.

15. Mueller C, Kallert S, Renner B, Stiassny K, Temmel AFP, Hummel T, Kobal G. Quantitative assessment of gustatory function in a clinical context using impregnated "taste strips". Rhinology. 2003; 41: 2-6.

16. Villa A, Connell CA, Abati S. Diagnosis and Management of Xerostomia and Hyposalivation. Therapeutic and Clinical Risk Management. 2015; 11: 45-51.

17. de Deco CP, Reis MRVS, Marchini AMPS, da Rocha RF, dos Santos MBF, Marchini L. Taste alteration, mouth dryness and teeth staining as side effects of medications taken by elderly. Braz J Oral Sci. 2014; 13(4): 257-260.

18. Kraaij S, Karagozoglu KH, Forouzanfar T, Veerman $\mathrm{ECl}$, Brand HS. Salivary stones: 
symptoms, aetiology, biochemical composition and treatment. Br Dent J. 2014; 217: E23: 1-6.

19. Percival RS, Challacombe SJ, Marsh PD. Flow rate of resting whole and stimulated parotid saliva in relation to age and gender. $\mathrm{J}$ Dent Res. 1994; 73: 1416-1420.

20. Engelen L, de Wijk RA, Prinz JF, van der Bilt A, Bosman. The relation between saliva flow after different stimulation and the perception of flavor and texture attributes in custard dessert. Physiol and Behv. 2003; 78: 165-169.

21. Matsuo R. Role of saliva in the maintenance of taste ssensitivity. Crit Rev Oral Biol Med. 2000; 11(2): 216-229.

22. Schiffman SS, Graham BG. Taste and smell perception affect appetite and immunity in the elderly. Eu J Clin Nutr. 2000; 54(3): S54-S63.

23. Delilbasi $C$, Cehiz T, Akal U, Yilmaz T. Evaluation of some factors affecting taste perception in elderly people. OHDMBSC. 2003; 4(6): 29-35.
24. Tango RN, Arata A, Borges AL, Costa AK, Pereira LJ, Kaminagakura E. The role of new removable complete dentures in stimulated salivary flow and taste perception. J Prosthodont. 2016; 27(4): 335-339.

25. Solemdal K, Sandvik I, Willumsen T, Mowe M, Hummel T. The impact of oral health on taste ability in acutely hospitalized elderly. PLoS ONE. 2012; 7(5): e36557.

26. Matsuo R, Yamamoto T. Effect of inorganic constituent of saliva on taste responses of the rat chorde tympany nerve. Brain Res. 1992; 583: 71-80.

27. Kauffman DL, Keller PJ. The basic proline-rich protein in human parotid saliva from a single subject. Arch Oral Biol. 1979; 24: 249-256.

28. Schiffman SS. Taste and smell loses in normal aging and disease. J Am Med Assoc. 1997; 278: 1357-1362.

29. de Castro MC, Raos-e-Silva M. Physiologic alteration of oral mucosa due to aging: a review. Acta Dermatovenerol Croat. 2005; 13(3): 184. 